\title{
Scent of a Woman: Performing the Politics of Smell in Late Medieval and Early Modern England
}

\author{
Holly Dugan \\ George Washington University \\ Washington, D.C.
}

On February 2, 2002, precisely four hundred years after its first recorded performance, Shakespeare's Twelfth Night (Or What You Will) was staged, once again, in front of a packed crowd at Middle Temple Hall. ${ }^{1}$ On this anniversary, the Globe Company granted the audience an intimate view of their "original practices" used in that night's staging of the play: audience members were given access to the candlelit dressing room where actors donned their costumes, applied makeup, and prepared themselves to begin. ${ }^{2}$ Highlighting the production's authentic costumes and the use of an all-male cast, the dressing sequence emphasized both gendered and historical transformations. ${ }^{3}$ To reviewers in London, the 2002 production of Twelfth Night was a culmination of the restored Globe's impact on contemporary productions of Shakespeare and the closest approximation to date of an early modern theatrical experience within modern constraints: this was Shakespeare, as one reviewer put it, without "any mustiness of the museum."4

Productions like the Globe's 2002 Twelfth Night reevaluate Shakespeare's plays with an eye both to contemporary and early modern theater contexts. With its voyeuristic peek at preperformance rituals, the production offered a visual feast that emphasized spectacular gender transformation. But what if one approaches these traditions and transformations with something other than an eye? What if one approaches them with a nose? Would current productions smell musty or fresh, old or new?

The 2002 production of Twelfth Night did not incorporate smell. Indeed, smell has not factored largely in translations of history into film or dramatic performance; as stage properties, scents have rarely impacted the critical work on late medieval or early modern material histories of the stage, no doubt due to the assumption that olfaction lacks both a history and an archive. 5 And, when it is addressed, olfaction emerges as an ahistorical para- 
dox, representing simultaneously the occidental and oriental, the classical and premodern, the civilized and primitive, the familiar and strange. ${ }^{6}$

Nonetheless, for late medieval and early modern men and women, olfaction was a key component of everyday life, including drama. Analyzing representations of scent as a dramatic trope within two distinct theatrical atmospheres - late medieval civic drama and early modern professional theaters - I argue that olfaction was a key component of both stages, particularly as a tool to enact "invisible" social differences. Though these stages — and the "women" represented on them — smelled very differently, their aromatic properties suggest that olfaction was a crucial part of theatricality throughout the sixteenth century.

As the 2002 production of Twelfth Night emphasized, within the context of the all-male late medieval and early modern English stages, the clothes made the woman: gender difference on the Globe's stage was interpreted as a visual spectacle. For scholars of early modern culture, cross-dressing has equally served as a lodestone, orienting and obfuscating early modern gender difference. These debates have examined early modern cross-dressing as both a historical and theatrical practice, querying how English audiences understood the boy actor's youth, his "feminine" costume, and his desirability on stage. ${ }^{7}$ And, as queer scholarship on fourteenth- and fifteenthcentury English drama argues, representations of gender and sexuality on late medieval stages also operated in visual ways, channeling "intense social and erotic desires" within the constraints of single-sex casting. ${ }^{8}$ The crux of these debates, so far, has focused on understanding how a character's social identity is conveyed through visual cues. ${ }^{9}$

But what if we insist on sixteenth-century stages with their smells, musty or otherwise? How would an analysis of the stage that accounts for smell operate? What might it say about the construction of social difference? By shifting focus from the visual realm toward other metaphoric and material discourses of the body, I argue that a sixteenth-century stage devoid of smell is anachronistic. Three remarkably odiferous plays underscore this claim: the Digby Mary Magdalene and Shakespeare's Antony and Cleopatra and Twelfth Night.

The Digby Mary Magdalene is not usually read alongside Shakespeare. There are, of course, important geographic, generic, and historical differences between Antony and Cleopatra, Twelfth Night, and the late medieval play, but all have remarkably pungent female characters. Mary Magdalene, Cleopatra, and Olivia are defined by their scents, each in strikingly different ways. The Digby's Magdalene, for example, is compared to 
numerous smells, including frankincense, clary, musk, cinnamon, grains of paradise, and gillyflowers - a curious blend of biblical, imported Levantine and English scents that construct her sexual debauchery and penitence within England's olfactory landscape. Cleopatra's perfume, unnamed in Shakespeare's play and his source documents, is described as strong, swift, and intoxicating, simultaneously invoking the English audience's desire for and anxiety about her sumptuous sexuality and the influence of aromatic exotica on male bodies. Olivia's scent, unlike the other two, is defined as somatic rather than spiced: her body pollutes Illyrian air, and her scent is repetitively described as an airborne plague that produces Illyria's atmosphere of gender and class inversion and sexual excess. Reading these plays together, my goal is to open up alternative meanings of gendered performances on late medieval and early modern English stages.

Late medieval London's civic and religious stages, like early modern professional theaters, were cultural and olfactory mixing grounds. Medieval "stinkards" and early modern "groundlings" mingled with nobles around England's indoor and outdoor stages of the fifteenth and sixteenth centuries. ${ }^{10}$ Bodies packed into tight medieval streets or crowded around pageant wagons no doubt produced a plethora of odors. Records indicate that in 1464, rosewater "fumigations" were employed to protect Edward IV's queen, Elizabeth Woodville, from the smell of the crowd during pageants that celebrated her arrival in London. ${ }^{11} \mathrm{~A}$ similar device was used to create aromatic rain and scented "hail" (made out of sweet rolls) in the York Pageant of Our Lady of $1486 . .^{12}$ And, on November 3, 1487, in a royal pageant for Henry VII, an elaborate machine "angel, descend[ed] from St. Pauls," and "cense[d] the King on his entry into the City after the battle of Stoke." Incense was purchased for numerous revels at Edinburgh Castle in the 1470s and 1480s. ${ }^{13}$ These civic and public stagings demonstrate that aromatics infused the pragmatics of medieval crowd control with religious symbolic meaning. ${ }^{14}$

Religious iconography was not the only realm of symbolism employed on medieval stages: symbolic links also existed between representation of scents on stage and the industries that either manufactured or were associated with them. Brimstone, or sulfur, was linked to both the fires that destroyed Sodom and Gomorrah and alchemical pursuits, marking men and women with the poisonous stench of sin. ${ }^{15}$ Furthermore, the mercantile structures that produced medieval scents (both pleasant and noxious) also provided readily identifiable tools for the casting — and staging — of late medieval English mummings, pageants, and play cycles. The godly splendor 
of heaven or paradise in key scenes of Corpus Christi cycles were often performed by goldsmiths (enacting what scholars identify as an "obvious" visual link between gold and kingly wealth), but just as often included assignments to the spicers and grocers guilds, revealing the ways in which scent participated in enacting divine splendor through more earthly industries. ${ }^{16}$

The Chester Spicers, for instance, staged the gifts of the Magi, the Norwich Spicers staged Adam and Eve in paradise, and the York Spicers staged the Annunciation and Visitation, demonstrating that spice signified the pleasures of paradise and divinity. ${ }^{17}$ Leather guilds (known for the powerfully noxious fumes that were byproducts of their commercial interests) were often assigned to perform the scenes involving the torments of hell, linking earthly, wretched scents with those of the devil. The Tanners' Guild of York performed the Fall of Lucifer and the Harrowing of Hell scenes; the tanners of Chester and Wakefield also performed the Harrowing of Hell. ${ }^{18}$ And the Chester Glovers and Parchment Makers staged the raising of Lazarus from the dead to life, linking death to the caustic smells of both industries (which used lime to preserve animal flesh). ${ }^{19}$

As many critics note, guild casting in the Corpus Christi plays linked divine geographies of heaven and hell to mercantile industries. ${ }^{20}$ This mélange of spiritual and earthly signifiers was part of the broader project of civic drama. ${ }^{21}$ Biblical tales came to life through the assignment of guild members to "appropriate" roles: the powerful concordance between lofty divinity and earthly industry enabled individuals to identify with the religious scenes performed. ${ }^{22}$ Scents, whether produced deliberately or as an unintentional byproduct of other commercial interests, were a vital component of performing such identifications.

Increasingly, scents were valued stage properties both indoors and out. In November 1527, an aromatic fountain provided an ambient setting for an interlude designed for Henry VIII in honor of the French ambassador. According to Hall's Chronicle, from its summit "was a fayre lady out of whose bestes [breasts] ran aboundantly water of mereuilous delicious saver." 23 A similar fountain was created for one of James I's coronation pageants in 1603 at Sopers Lane, an area known for its medieval associations with the spicers. ${ }^{24}$ This fountain, symbolizing Arabia, had five founts representing the senses that flowed with milk, wine, and scented balms, allegorically representing James's ascent as a phoenix rising from Arabia's spiced nest. ${ }^{25}$ The founts, representing the five senses, were languorous with grief until James's arrival, at which point they "sprung" to life, embodying royal magnificence. 
Perfumes were also employed in Elizabeth's courtly revels. As account records from the Office of the Revels document, numerous performances in the early years of her reign utilized bushels of aromatic herbs, roses, and vegetation - either strewn about the stage floor or construed into elaborate scenery. ${ }^{26}$ In 1572, Robert Moorer, an apothecary, provided musk, ginger, and clove comfits, along with quarts of rose water and pints of spike water, to create scented flakes of ice and hail in the "Masque of the Janus" presented to the queen. He also supplied similar ingredients for the "Masque of the Wildman," performed at court on Twelfth Night, 1573.27

Sixteenth- and seventeenth-century mayoral processions similarly made use of scents to display London's civic and economic power. ${ }^{28}$ Thomas Middleton's Triumphs of Honour and Industry (1617) and Triumphs of Honour and Virtue (1622) employed elaborate staging of "all manners" of "spice plants and trees bearing odour," including ginger, nutmeg, clove, and pepper. These guild-sponsored spectacles staged the "triumph" of new kinds of merchandise in London markets through multisensorial displays, employing scent ingredients, waterworks, and fireworks in water displays and dumb shows. As Barbour argues, these shows positioned London in relationship to burgeoning global trade networks. ${ }^{29}$ For example, Middleton's Triumphs of Honour and Virtue staged the entrance of "a black personage representing India, called, for her odours and riches, the Queen of Merchandise," who "advanceth herself upon a bed of spices, attended by Indians in antique habits," offering India's native, abundant "gums and fragrant spices" for consumption. 30 Whereas the queen admits that such fragrant gifts cannot compare "with odours whose scent does ne'er decay" such as "youth," "eternal life," and "sweet truth," from an audience member's point of view, such an abstract message would hardly be the most salient feature of the display. Numerous pamphlets detailing similar mayoral pageants in the sixteenth century document that spices were often tossed into the crowd. ${ }^{31}$

Exotica, however, were not the only scents used in these stagings. Clouds of "sulpherous" mists, as well as a detailed tableau vivant of the five senses, were employed in Middleton's Triumphs of Truth (1613); his Triumphs of Health and Prosperity (1626) employed a barge "adorned and garnished with all variety of odoriferous flowers; . . the work itself encompassed with all various fruits, and bears the name of the most pleasant garden of England, the noble city of London, the flowers emanating the sweet odours of their virtue and goodnesses, and the fruits of their works of justice and charity." 32 Scents, as stage properties, fulfilled a host of practical purposes, fusing crowd control, religious symbolism, monarchical power, civic procession, and mer- 
cantile interests with thematic content in a wide variety of dramatic performances. When read within the context of late medieval and early modern English stage history, these descriptions reveal that we have dramatically underestimated the ways in which the staging of smell mattered in the past.

Produced from spices originating in the Holy Land and native botanicals, medieval religious scents represented a myriad of geographic, political, and economic networks. The exotic, profane, and holy all were invoked by scented incense and balm. In medieval cultures, no other figure better represents the various nature of scent than the saint whose emblem was perfumed balm: Mary Magdalene. Earthly scents not only indicated proximity to divinity and salvation, but they also tempted as apertures to sin and damnation.

The medieval Catholic liturgy used perfumed incense as a tool of transformation, translating parishioner's prayers into a sweet substance that could transcend the earthly realm and rise up to God. Deriving from ancient Judaic and Arabic traditions, the use of incense first emerged as part of the Christian liturgy in the fourth century. As church architecture evolved and expanded, incense became a key signifier of religious transformation. ${ }^{33}$ In later medieval practice, prayer might involve a number of sensory experiences helping to create proximity to divinity: the devoted prayed before images of saints, burned incense and candles, touched relics, and chanted. But for most men and women in the later Middle Ages, such sensory nearness to the divine was mainly experienced only once a year during the celebration of the Easter mass, the apex of the medieval church calendar. Following a period of Lenten preparation, in which parishioners were to confess sins that separated them from God, and the Good Friday mass at which the the processional cross was enshrouded and the altar was stripped of ornaments, candles, and cloths, symbolizing the absence of Christ in his death, the Easter mass, through the reception of the Eucharist, was a celebration of reconciliation and literal closeness to Christ's body. ${ }^{34}$

Late medieval liturgical drama staged such proximity to divinity through incense. As the Quem quaeritis in sepulchro dialogue emphasizes, the spiced funeral balms of the three myrophores (including Mary Magdalene) were linked to liturgical censing. ${ }^{35}$ Such rituals emphasized a multisensorial transformation. According to Thomas J. Heffernan and E. Ann Matter, the impact of liturgical censing in even the humblest of parish churches would have been profound: incense "coaxed a series of complex associations as it billowed up from the thurible in the half gloom of the dimly lit church. It 
might have reminded parishioners of the incense brought from the East by the Magi, and possibly of the angel in Revelation (Rev. 8:3-8) who, through incense, wrought thunder, lightning, and earthquakes." The pungent odor of incense clearly "pointed to a new order, a realm different from that in which they dwelled."36

The Magdalene's icon was at the center of such transformations. Yet her saintly tale emphasizes her precarious relationship to divinity. A curious amalgamation of biblical heroines, she is the only female saint who is not a wife, virgin, martyr, or mother. ${ }^{37}$ Her ability to represent the power of temptation as well as redemption may explain her widespread cultural appeal in the late medieval period. Both aspects of her saintly life are conflated in her personal attribute of perfumed balm. In medieval visual cultural traditions, the Magdalene was identified through a number of attributes: a red cloak, long, loose hair, tears, a book, or an ointment bottle. These visual clues help identify her as a reformed prostitute — the red cloak and long, unruly hair indicating her past promiscuousness, the book and tears symbolizing her repentance. ${ }^{38}$ The ointment bottle containing scented oil or balm works as a hinge between these two aspects of her legend and thus is critical to understanding (and staging) both Mary Magdalene's descent into cupidity and her penitent submission at the feet of Christ.

In many ways, the Digby Mary Magdalene dramatizes this dual representation of sexual and religious transformation staged through contemporaneous politics and trade. Little is known about its author, its date, or its production history, though scholars estimate the play was first performed between 1480 and 1530 and that it can be assigned to East Anglia. ${ }^{39}$ With over two thousand lines and possibly as many as fifty-two scene changes, this secular play is, in Theresa Coletti's summation, "awesomely eclectic" and "contains nearly every theatrical device known to the late medieval playwright." 40 Clifford Davidson argues that the play's sprawling structure and seemingly extravagant use of props suggest that it was probably a town production, most likely sponsored by a guild in honor of the Magdalene's feast day, July $22 \mathrm{nd} .41$ If scene descriptions are any indication of the use of props within an actual performance, the play would have featured numerous costume changes, elaborate machinery (including a large ship that could travel back and forth across the stage and a device that could enable devils to exit the Magdalene's mouth on cue), as well as numerous props to simulate the banquet and tavern scenes, including a plentiful supply of "awromatics."

Based on both the Golden Legend and the Gospels, the play depicts

Dugan / Scent of a Woman 235 
the biography of the Magdalene, balancing the demands of church dogma against the guild economics that most likely financed its production. ${ }^{42}$ As one scholar notes, the play "is as composite in structure" as the "Magdalene figure is in nature." 43 Organizing the saint's life into a dramatic and coherent triptych, the play uses perfumed incense as a bridge between the first half's enactment of sin and repentance and the second half's staging of the miraculous conversion of the King of Marcyll. In several important "perfuming" scenes that manipulate Mary Magdalene's saintly emblem, the play stages both the sinful nature of a luxurious touch and the venerating touch of salvation.

The play thus participates in the late medieval fascination - and unease - with this popular saint's complicated role as both sexual sinner and penitent role model. ${ }^{44}$ As Coletti argues, the Digby play was part of a broader cultural interest in maintaining feminine virtue through social order, which was evidenced in church dogma, vitae, and popular conduct books. These documents sought to "explain, though not excuse, the Magdalene's associations with sexual vice," exploring "how the figure who was understood as Christ's intimate follower and beloved could have been guilty of sexual sin." 45 The Digby play explores this question through staging proper and improper engagement with worldly goods. The repeated utterances of "Oh, Mahommed!" in its opening scenes situates the Magdalene's descent from virtue anachronistically within a late medieval political geography of trade and empire. Within such a temporal displacement, the play's many calls for "wine and spices" are tools of celebration within its narrative as well as references to stage properties culled from medieval markets. Likewise, the play's numerous meditations on the smell of spice ingredients educate its audience about navigating the pungent and sweet scents of the medieval church and market.

It is, after all, the diabolical King of Flesh who convinces Mary to leave her father's home and enter the social realm of the tavern where she is debauched. His is a floral, spiced dominion:

I, Kyng of Flesch, florychyd in my flowers, Of deyntys delycyows I have grett domynacyon!

So ryal a kyng was neuyr borne in bowrys, Nor hath more delyth, ne more delectacyon!

For I haue comfortatywys to my comfortacyon:

Dya galonga, ambra, and also margaretton-

Alle pis is at my lyst, azens alle vexacyon! 
All wykkyt thyngys I woll sett asyde.

Clary, pepur long, wyth granorum paradysy,

Zenzybyr and synamom at euery tyde-

Lo, alle swych deyntyys delycyas vse I! 46

[I, King of Flesh, flourishing with flowers with dominion over such dainty delicacies! So royal a king was never born in any bower, nor has more delight, or more delectation! For I have comforting medicines that strengthen: galingale, ambergris, and also marjoram — all this is all my desire against vexation! All wicked things I will set aside. Clary, pepper, grains of paradise, ginger, and cinnamon at every tide — lo, I use and delight in all such dainties!]

He is accompanied by a sparkling "lady lechery," "glittering" with "amorousness," referring, undoubtedly, to the greasy, hot, savory nature of the King of Flesh's scents. ${ }^{47}$ Filled with desire for the King, Lady Lechery is described as glittering. Her shiny skin invokes the materiality of the King of Flesh's "comforting medicines," specifically greasy ambergris. His scent-clary, pepper, grains of paradise, ginger, and cinnamon - work as medicinal ingredients against vexation through emitting and enacting sensuality and odiferous pleasure. These ingredients, commonly imported and sold in the late fifteenth century by the Company of Grocers, mix a blend of Oceanic, northern European, Egyptian, African, and English scents, demonstrating that sensual delight might be found in global amalgamations. ${ }^{48}$

Lady Lechery, also referred to in the manuscript as Luxuria and Luxurysa, signifies both worldly and sexual temptation: luxuria was a generic term for luxury goods as well as an ecclesiastical legal term of art meant to denote both gluttony and a hierarchy of other sexual sins, beginning with heterosexual sex outside of marriage and progressing to incest, sex with priests, and crimes against nature. ${ }^{49}$ Luxuria was commonly depicted as two lovers embracing or as a rote depiction of debased feminine sexuality. Although the play enacts the Magdalene's descent into vice through depicting a heterosexual liaison, Lady Lechery enacts the sinful temptation latent in both her worldly and sexual allure. She introduces the Magdalene to the worldly goods of the tavern and its many sexual temptations. Described by the King of Flesh as a "flowyr fayres of femyntye," Lady Lechery's beauty mirrors the Magdalene's (described earlier in the play as "ful fayur and ful of femynyte"). Escorted by a Bad Angel, Lady Lechery breaches the Magdalene's castle. The 
scene is suggestively erotic, linking female beauty with vanity and vice. ${ }^{50}$ The Magdalene is seduced by Lady Lechery's amiable tongue:

Your debonarius [debonair] obedyauns ravyssyth me to trankquelyte!

Now, syth ye desyre in eche degree,

To receyve youw I have grett delectacyon!

Ye be hartely welcum onto me-

Your tong is so amyabyll, devyded [measured] wyth reson. (71-75)

Lady Lechery's greasy, "sparkling” amorousness metaphorically and materially emphasizes the power of scent to penetrate geographical and bodily boundaries.

Despite the Magdalene's sexual contentment in the floral bower with the gallant Curiosity, the Ghost of Goodness quickly convinces her to search for a salve for her soul; under his counsel, the Magdalene pursues the Prophet, seeking to trade her erotic, sweet balms for "an oil of mercy," dramatically enacting the medieval notion of contrapasso, a structure of penitence demanding that any absolution match the nature of the $\sin .51$ The play dramatizes her anointing of Christ's feet as part of his parable of the two debtors. When read on the page, it is not an erotic scene; Mary's wretchedness provides a useful illustration for Christ's tale of debt and forgiveness. Some critical editions of the play, however, interpolate Simon's shock at Christ's reception of the Magdalene into the text of the play, inferring that medieval audiences would recognize that the penitent Magdalene had been contaminated by Lady Lechery and that any subsequent physical touch from her would spread the sin of luxuria. If staged with scents, this small dalliance within the broader pedagogical narrative could dramatically enact contrapasso. The sweet balm conjures earlier scenes of the sparkling amorousness of Lady Lechery, the fragrant bliss of the bower, and the Magdalene's search for a salve that could anoint and save her soul.

Lest there be any doubt about the Magdalene's handling of Christ's body, the play emphasizes that once penitence is achieved the Magdalene must abandon her sweet balms for churchly incense. When the Magdalene attempts, once again, to approach the resurrected Christ with her sweet balms, Christ issues forth the command "touch me nott" and offers her a lesson in olfactory abstraction: he is now like a gardener, tending a "gardyn" of humanity that "is watered with tears" and "springs virtue" that smells "full sweet." 52 
This abstraction is spun out even further: Christ provides yet another description of scent, this time on the proper scent of a woman, the Virgin. Almost halfway through the drama, Christ addresses the audience from the heaven stage and meditates on the blessedness of the Virgin. Lamenting that his mother's virtue cannot be described by language, he describes her instead through an epistemology of scent. In a play that stages Mary Magdalene's path toward sainthood, Christ's meditation on the Virgin may seem surprising, and in fact, it is the only moment in the play in which the Virgin is mentioned. She is incense, cinnabar, musk, gillyflower:

My blyssyd mother, of demvre femynyte,

She is the precyus pyn, full of ensens,

The precyus synamvyr, the body thorow to seche.

She is the mvske azens the hertys of vyolens,

The jentyll jelopher azen cardyakyllys wrech.

The goodnesse of my mothere no tong can expresse,

Nere no clerke of hyre, hyre joyys can wryth. (1356, 1360-65)

[My blessed mother, of demure femininity ... She is a precious pyx, full of incense, the precious cinnabar, which purifies her body. She is the musk against the hearts of violence, the gentle gillyflower against such cardiac pain. No tongue can express her goodness. No clerk for hire can write her joy.]

Occurring just after the King of Marcyll's sacrifice to Mahommed and just prior to Mary Magdalene's journey to France to convert him, the description of the Virgin's scent marks a crucial transition. Here the story evolves from the tale of a penitent prostitute into the story of a saint. Christ triumphs over the King of Flesh, displacing his worldly amalgamation of ambergris, galingale, and clary with powerful musk, precious incense, cinnamon, and English gillyflower. Unlike Lady Lechery's glittery-scented amorousness that belies her carnal touch, the Virgin's scent is sweet, smoky and pure, blending religious incense most likely encountered in medieval cathedrals, with expensive cinnabar and English carnations, both known for their medicinal properties.

Within the Digby Mary Magdalene, smell operates as a moral compass and material indicator of both worldly sin and vice and saintly, feminine virtue. To triumph over the King of Flesh's ambergris, Christ describes his mother's abstract, smoky scents. The play's overt taxonomy of scent, and staging of saintly and sinful desires, demonstrates that olfaction provided a thematic, 
metaphoric — and perhaps material — tool to represent women on England's all-male stages. When read against this earlier historical context, the smells of Shakespeare's stage accrue powerful metaphoric and material meanings.

Whereas the Digby Mary Magdalene dramatizes identity transformation in its linking of feminine virtue with scents encountered in late medieval English churches and markets, Shakespeare's Antony and Cleopatra explores perfume as a stage property. ${ }^{53}$ In this play, Cleopatra's power to alter Roman, martial will is identified as an effect of her strange and invisible perfume. Cleopatra's perfume, at least according to Enobarbus, represents the metaphoric and geographic difference between the duties of Rome and the pleasures of Egypt. ${ }^{54}$

Unlike the Magdalene's perfume, Cleopatra's scents are not named in Shakespeare's play. Rather than list specific ingredients, Shakespeare describes Cleopatra's perfume in general terms as swift, strong, and intoxicating. As Enobarbus famously notes, Cleopatra is a master of theatrical effects, specifically multisensorial ones. In his oft-quoted recounting of the couple's initial meeting in Tarsus, Enobarbus describes how, even before Antony saw her, Cleopatra "pursed up" his heart "upon the river Cydnus," (2.2.192). Enobarbus's account contradicts Antony's belief in love at first sight, expressed in the play's opening scenes: Antony fell in love not at first sight but at first smell. 55 The setting underscores this view: Tarsus, in Turkey, was the legendary home of King Caspar, one of the three Magi, who offered gifts of myrrh, and was well known for its biblical associations with the Epiphany - and its spicy gifts. ${ }^{56}$ Summoned there by the Roman imperium seeking to demand tribute from wealthy Egypt, Cleopatra exploits Roman assumptions about luxurious Egyptian exoticism by parading spiced goods, a strategy familiar to the play's audience, which, as noted above, was familiar with mayoral displays of London's civic and economic power.

Enobarbus describes Cleopatra's barge in terms of a multisensorial experience: it has a golden deck, purple sails "so perfuméd that / The winds were lovesick with them," and silver oars that beat to the tune of flutes (2.2.199-200). Fanned by dimpled boys, Cleopatra's visage "beggar'd all description," and Enobarbus notes that it was her perfume that first attracts Antony:

From the barge

A strange invisible perfume hits the sense

Of the adjacent wharfs. The city cast

240 Journal of Medieval and Early Modern Studies / 38.2 / 2008 
Her people out upon her, and Antony,

Enthroned i'th' market-place, did sit alone,

Whistling to th' air. (2.2.217-22)

Enobarbus remarks on the strange, invisible power of perfume to bewitch Antony: Cleopatra's scents seem designed to spread a wide sphere of influence. As Jonathan Gil Harris argues, Cleopatra's power on the Cydnus depends upon narrative description of visual splendor: "the curious lack of physical detail offered by Enobarbus about Cleopatra’s displayed body suggests that her power subsists in her very invisibility, her publicly paraded absence." 57 Whereas Harris argues that such invisibility underscores a scopophilic, narcissistic pleasure central to early modern theaters, I argue that such invisibility signals early modern theatrical practices — and pleasures — that relied on other sensory mechanisms, particularly "strange" and "invisible" scents.

Enacted on an early modern stage, where "some squeaking Cleopatra boy" portrayed Shakespeare's queen, Enobarbus's description of Cleopatra's beguiling entrance in Tarsus underscores the power of her self-presentation (5.2.216-17). Juxtaposed with Octavia, who "shows a body, rather than a life" and is more "a statue than a breather" (3.3.20-21), Cleopatra's sexual power (at least in Enobarbus's estimation) demonstrates how scents, as stage properties, may mark the scope of sexual influence more effectively than vision. Although Caesar's Roman "eyes" are upon Antony, knowledge of his "affairs come to [Caesar] on the wind" (3.3.63-64).

To modern critics, Shakespeare's Egypt is an exoticized, intoxicating zone conflated with its queen. ${ }^{58}$ Critics have described Shakespeare's Egypt as a "carnivalistic," "mercurial," "effeminate," "intoxicating," "timeless," and "degenerate" zone-Rome's antithesis — raising real questions for theater historians about how it may have been staged. ${ }^{59}$ As Barbara Hodgdon notes, until recently, the spatial and geographic extremes presented in Antony and Cleopatra seemed unperformable. ${ }^{60}$ Jonathan Dollimore asks a similar question: "[Antony's] sexuality is structured by those very power structures he's prepared to sacrifice for his sexual freedom — Rome for Egypt . . . [b]ut how to convey this in production?"'61 Cleopatra's "infinite variety" (2.2.241) reveals the strategies and limitations of visual structures of materiality used to enact gender and sexuality on Shakespeare's stage. The play's oblique olfactory references suggest that scents signified Cleopatra's power and desirability in ways visual codes could not capture.

Shakespeare's Twelfth Night similarly interrogates early modern

Dugan / Scent of a Woman 241 
theatrical conventions used to represent gender, staging another powerfully odiferous heroine: Olivia. As Cleopatra ends, so Olivia begins. Sequestered away in self-imposed mourning over her dead brother for over a year, Olivia has vowed to "abjure the sight and company of men." 62 Her decision tortures Orsino, who longs for Olivia. Thus, Twelfth Night begins with a striking spectacle: a body delighted — and tormented — by unseen influences. Unlike Antony and Cleopatra's staging of excess pleasure, Twelfth Night's many metaphors of scent are part of the play's broader inquiry into staging multisensorial experience of pleasure.

Attempting to describe the experience of love, Orsino offers a confusing, synesthetic metaphor. Identifying music as "the food of love," Orsino proclaims that sounds provoke and nauseate him. Rather than describe the qualities of the sound, Orsino instead describes how the sound smells of violets:

O, it came o'er my ear like the sweet sound

That breathes upon a bank of violets,

Stealing and giving odor. Enough, no more,

'Tis not so sweet now as it was before. (1.1.5-8)

Orsino's narcissistic experience of love makes a certain amount of sense, for as the play quickly reveals, his beloved, Olivia, is cloistered. Left only with fleeting, feverish memories of her, Orsino is haunted by his desire:

$\mathrm{O}$, when mine eyes did see Olivia first

Methought she purged the air of pestilence;

That instant was I turned into a hart,

And my desires, like fell and cruel hounds,

Ever since pursue me. (1.1.18-22)

Rather than signifying a presence, Orsino's sensory experience of momentary pleasure marks only painful longing and loss. Twelfth Night's opening scene suggests that desire is as capricious as it is contagious. Denied access to his beloved, Orsino's desire is fanned and cooled only by the Illyrian winds.

Olivia's sequestration is set in stark relief with the introduction of the play's true heroine, Viola, who, surviving a shipwreck, has come to Illyria and intends to help Duke Orsino, disguising herself as a eunuch to do so. ${ }^{63}$ Subtly suggesting that it is Olivia's scents that trigger Orsino's violent, tumultuous desires, Viola notes the dangerous ability of nature to enclose 
interior "pollution" within a beautiful exterior "wall," even as she deliberately manipulates her own appearance to conceal her gender (1.2.44-46). Described by Olivia's steward Malvolio as "not yet old enough for a man, nor young enough for a boy; as a squash is before 'tis a peascod, or a codling when 'tis almost an apple," Cesario (Viola) is an unripened youth (1.5.150-53).

As a young woman, Viola's bodily scents are not strong and can therefore be masked through cross-dressing: Cesario's "missing part" materializes through discourses of scent prevalent in the period. A peascod, or pea pod, is an unripe squash, but a peascod also referred to a fashionable doublet ending in a stiffly quilted, protruding lower part. A codling is an unripened apple, but it also refers to the scrotum of a beaver (a prized New World resource noted for its value in perfuming industries), and for a brief time in the early seventeenth century, it could refer to green peas. It is hard to overlook Shakespeare's phallic (and odiferous) punning on these terms. As Malvolio's fruity description of Cesario reveals, there is some anxiety about how this creature will ripen. In addition, Cesario's youthful pea-plants hint at other schemas of scent and desire that, I argue, underscore the foul scent of Olivia's "great Ps" (2.5.72).

The play's trope of love as an airborne scent is strengthened by the play's comic subplots. In a scene between Feste, Sir Andrew, and Sir Toby, Sir Andrew remarks on Feste's "sweet breath." The scene quickly erupts into a series of puns on music and odor, extending the first act's metaphoric synesthesia. After Feste performs a love song, both characters barrage him with a strange string of compliments:

SIR ANDREW

A mellifluous voice, as I am a true knight. SIR TOBY

A contagious breath.

SIR ANDREW

Very sweet and contagious, i’faith. SIR TOBY

To hear by the nose, it is dulcet in contagion. (2.3.49-52)

Feste's sweet and contagious breath does not seem all that distinct from Orsino's invocation of the sweet sounds "stealing and giving odors" (1.1.57). Sir Toby concludes that Feste's love song could sweetly carry the contagion of love, if only heard by the nose. Metaphors of scent participate in a synes- 
thetic overload and the nose emerges as a primary organ of desire: music is the food of love, best heard through the nose.

Sir Toby's remark links desire with metaphors of scent and contagion as these jokers hatch a plan with Maria to humiliate Malvolio. When Maria first suggests the plan, Sir Toby remarks, "Excellent, I smell a device." Sir Andrew concludes, "I have't in my nose too" (2.3.151-52). Such olfactory puns underscore Twelfth Night's logic of desire, at Olivia's expense. ${ }^{64}$ As Callaghan argues, Olivia's body is overtly ridiculed in this ludicrous scene. Malvolio reads the falsified letter, and remarks ostensibly on his mistress's genitalia: "By my life, this is my lady's hand. These be her very C's, her U's, and her T's and thus she makes her great P's" (2.5.82-84). Sir Toby, Sir Andrew, and Fabian laugh from the sidelines at Malvolio's buffoonery and the comic display of Olivia's body. Although Callaghan reads this moment as indicative of the play's broader concerns with class transvestism, Malvolio's exaggerated desire for Olivia seems to differ from Orsino's only in scope. ${ }^{65}$

As Malvolio humiliates himself, Sir Toby and Fabian narrate Malvolio's reading. Sir Toby utters, "O ay. Make up that, he is now at a cold scent." Fabian replies: "Sowter will cry upon't for all this, though it be as rank as a fox" (2.5.117-19). This exchange bestializes Malvolio, likening him to a "sowter" (hound dog) on a scent of a "rank fox," while it also likens Olivia's genitalia to the rankness of a fox. Such humor suggests that Olivia is not only an invisible odor but that her presence actually reeks. Like Christ's description of the Virgin in the Digby Mary Magdalene, and Enobarbus's evocation of Cleopatra, Olivia is absent while her body is metonymically represented on stage through metaphors of scent.

Even Cesario's courtship plays on the central link between Olivia's sexuality and her smell. Immediately after the scene of Malvolio's humiliation at the expense of his mistress's body, Cesario addresses Olivia with a strange compliment: "Most excellent accomplished lady, the heavens rain odors on you" (3.1.76-77). Although this odd remark highlights Cesario's verbal acumen, Cesario's remark underscores the theatrical construction of Olivia's bodily odors. Prior to this scene, Olivia has metonymically been called a cunt and described as reeking like a rank fox. The heavens now metaphorically rain odors on her, raising interesting questions about the play's ability to stage such a scene.

Olivia's bodily odors, like the Magdalene's religious scents, and Cleopatra's dramatic airs, are theatrical constructions. The association of "rank" smells with Olivia's body is a theatrical ploy used to divest her 
of social power. As such, it has profound consequences for the structures of gender and desire articulated elsewhere in the play, for it implies that desire can exist on stage without the presence of any body, regardless of gender.

Because Olivia's sexuality manifests itself in the air, it is possible for her desire to be heard through the right nose: enter Sebastian. Sebastian's ability to play the "woman's part" depends on his youthful, indeterminate scent. After Cesario breaks Olivia's heart, Olivia sends Feste to retrieve him. When Sebastian fails to recognize him, Feste mocks Sebastian's confusion:

No, I do not know you, nor I am not sent to you by my lady to bid you come to speak with her, nor your name is not Master Cesario, nor this is not my nose, neither. Nothing that is so, is so. (4.1.5-8)

Feste marks the absurdity of Cesario's attempts to deny his relationship with Olivia: one's identity is as clear as the nose on one's face, or the scent one emits. Of course, Feste has mistaken Cesario's "nothing" for Sebastian's "something." Feste's unknowing pun on phallic inversion reveals the interchangeability of the youthful, twinned bodies. His pun works to resolve the romantic crisis of the play, drawing Olivia out of her self-imposed exile by replacing Olivia’s desire for a boyish girl (Cesario) with her desire for girlish boy (Sebastian).

Not surprisingly, Sebastian interprets Feste's puns as an insult: "I prithee vent thy folly somewhere else. Thou know'st not me" (4.1.9-10). Sebastian's use of the term "vent" works to discount Feste's utterances as well as Feste's familiarity with him. Sebastian suggests that Feste "vents," or releases into the air, stark raving madness as well as unpleasant aromas. Feste responds angrily:

Vent my folly! ... Vent my folly — ... I prithee now ungird thy strangeness, and tell me what I shall vent to my lady? Shall I vent to her that thou art coming? (4.1.11-14)

Feste's heated remarks demand a profound transformation: his command to Sebastian to "ungird thy strangeness" is an appeal to drop the charade of confusion and to replace olfactory identifiers with visual ones.

Thrilled finally to have Cesario's affection, Olivia immediately prepares for marriage, while Sebastian proclaims that

This is the air, that is the glorious sun,

This pearl she gave to me, I do feel't and see't, 
And though 'tis wonder that enwraps me thus,

Yet 'tis not madness. (4.3.1-4)

Sebastian's proclamations yoke Olivia's air to Orsino's earlier metaphors of desire: if Olivia's air has truly been purged of her rank odor, it is because her desire now has a gender-appropriate recipient. Finally (if unknowingly) directed at the appropriate object, Olivia's sexuality is no longer described as a rank presence.

Through metaphors of smell, Olivia's illicit, invisible desire for Cesario is represented yet ultimately disavowed: part of what has allowed Olivia to confuse Sebastian with Cesario (and vice versa) is the random, infectious nature of the aromas of bodies. The play ends with the promise of Viola and Orsino's wedding, yet leaves the space of marriage open for future mix-ups: Malvolio storms off and Viola remains in drag. ${ }^{66}$ Indeed, Feste's closing song suggests that the specter of female desire still hangs in the air: "it raineth every day" (5.1.379). If the heavens can rain such odors once, they can do so again. The question remains: which odors will accompany the song?

Despite critical assumptions that England's all-male stages circumscribed, interiorized, or policed women's bodies, olfaction provided a rich material and metaphorical tool to represent gender and desire. Perfumes were powerful stage properties in late medieval liturgical and civic drama and on early modern professional stages. They materialized invisible, ephemeral, and mutable pleasures, particularly those that constructed early modern theatrical fantasies about gender and desire. More than a bodily interior state or a sartorial spectacle, the scents of these women mark divinity, damnation, and, most importantly, desire in spaces where there were no women.

3

\section{Notes}

I'd like thank Valerie Traub, Peggy McCracken, Kelly Williams, and Michael Cornett for their careful editing of this essay. I'd also like to thank three anonymous reviewers of the article, the participants of the Shakespeare Association of America's 2004 seminar on early modern senses, and the members of the University of Michigan's early modern colloquium for their thoughtful contributions to core concepts of this article.

1 In 1602, John Manningham, a young lawyer, recorded witnessing "a play called Twelfth Night" at a feast. See Michael Baird Saenger, "Manningham on Malvolio," Shakespeare Newsletter 43.4 (1993): 159-61. 
2 See Alan Stern, “Acting, Not Gender, Crucial to Shakespeare," Denver Post, September 13, 2002.

3 Costumes were limited to materials available to the Lord Chamberlain's Men in 1602. Music was played on instruments available to Elizabethan madrigals (culminating in a festival dance scene like those that ended Elizabethan comedies), and, as the dressing sequence overtly emphasized, single-sex casting was used.

4 Paul Taylor, "A Night to Remember; Twelfth Night Has Returned to Middle Temple Hall 400 Years after Its First Performance; Paul Taylor Discusses 'Authentic Shakespeare' with Mark Rylance, Its Astounding Olivia," The Independent, February 2, 2002. By most accounts (mine included), Tim Carroll's production and Mark Rylance's artistic direction and performance as Olivia were critical successes, harnessing recent scholarly turns toward historicism and presenting them to a variety of popular audiences.

5 Consider, for example, Jonathan Gil Harris and Natasha Korda's definition of stage properties as "all the moveable physical objects of the stage." Harris and Korda note that "[m]uch of the recent scholarship on the early modern world of goods, however, has avoided theoretical reflection on what constitutes materiality. As a consequence, there has been a pervasive tendency to equate the 'material' with the 'physical.' 'Jonathan Gil Harris and Natasha Korda, Staged Properties in Early Modern English Drama (Cambridge: Cambridge University Press, 2002), 1-2, 17.

6 Consider, for instance, Patrick Süskind's best-selling novel Perfume. Süskind's tale, set in eighteenth-century France, provides a fascinating and accurate glimpse of the material history of French perfuming industries. Yet, it offers only a glimpse: the material history of perfume serves only to titillate a contemporary (and misogynistic) take on the link between sex, gender, and perfume in the past. Driven wild by the natural scents of prepubescent girls, Süskind's protagonist murders and distills their "essences" into a powerful perfume that results in sexual orgies with one sniff. See Patrick Süskind, Perfume: The Story of a Murderer (New York: A. A. Knopf, 1986).

7 The high-water mark of such scholarship remains Stephen Orgel's Impersonations, which argued that overextending the concept of the Elizabethan all-male stage could have the effect of "dislocating desire" and underestimating women's relationships to the stage, as amateur players and audience members alike. See Impersonations: The Performance of Gender in Shakespeare's England (Cambridge: Cambridge University Press, 1996). Querying the visibility of the cross-dressed figure on the stage, Tracy Sedinger argues instead that the cross-dresser "is not a visible object but rather a structure enacting the failure of a dominant epistemology in which knowledge is equated with visibility.” See Tracy Sedinger, "If Sight and Shape Be True': The Epistemology of Crossdressing on the London Stage," Shakespeare Quarterly 48 (1997): 64,70 . In her argument about body politics in Twelfth Night, however, Dympna Callaghan suggests that the homosocial space of the Renaissance stage precludes any attempt to read transvestized femininity in Twelfth Night for positive, feminist meanings. See "'And all is semblative a woman's part': Body Politics and Twelfth Night," in Callaghan's Shakespeare without Women: Representing Gender and Race on the Renaissance Stage (New York: Routledge, 2000), 32.

8 Valerie R. Hotchkiss, Clothes Make the Man: Female Transvestism in the Middle Ages 
(New York: Garland, 1996); Claire Sponsler, "Outlaw Masculinities: Drag, Blackface, and Late Medieval Laboring-Class Festivities," in Becoming Male in the Middle Ages, ed. Jeffrey Jerome Cohen and Bonnie Wheeler (New York: Garland, 1997), 321-48; Robert L. A. Clark and Claire Sponsler, "Queer Play: The Cultural Work of Crossdressing in Medieval Drama," New Literary History 28 (1997): 319-44.

9 On women's roles within early modern theater companies, see Natasha Korda, “Women's Theatrical Properties," in Staged Properties, ed. Harris and Korda, 202-29. "Transvestized," as many scholars have pointed out, is a loaded term linking early modern cross-dressing to eroticism. Valerie Traub, Desire and Anxiety: Circulations of Sexuality in Shakespearean Drama (New York: Routledge, 1992), 118-19, notes that it is productive to think of the erotic effects of "transvestized" theater as dispersed throughout the "fabric" of the text, "rather than located and fixed within one character's desire." Ann Rosalind Jones and Peter Stallybrass expand discussions of transvestism and eroticism on the early modern stage, arguing that the ritual of "undressing" fetishized and eroticized assumptions about the body beneath clothing. See Ann Rosalind Jones and Peter Stallybrass, Renaissance Clothing and the Materials of Memory (Cambridge: Cambridge University Press, 2000), 217-19.

10 Wickham uses stinkard to denote peasant audience members of a wide variety of medieval stages. Glynne Wickham, Early English Stages, Volume 1, 1300-1576 (1981; repr. London: Routledge, 2002), 59. Analyzing the concordance between ethics and hearing in medieval grammar, Valerie J. Allen, "Broken Air," Exemplaria 16 (2004): 9, argues that there is a sexual connotation to stinkard, signifying foul excess: "[t]he -ard ending, according to the Oxford English Dictionary, denotes 'one who does to excess.' Of great popularity in the sixteenth century, the suffix was just the ticket to describe this noisy explosive. The pet-ard meant something like 'Old Fart Butt,' and carried the same derogatory innuendo as did 'dotard,' 'drunkard,' 'coward,' 'laggard,' 'stinkard,' 'wizard,' and, worst of all, 'Spaniard.'”

11 Wickham, Early English Stages, 96.

12 Ibid.

13 Anna Jean Mill, Mediaeval Plays in Scotland (New York: B. Blom, 1969), 57.

14 Ian Lancashire, Dramatic Texts and Records of Britain: A Chronological Topography to 1558 (Toronto: University of Toronto Press, 1984), 184, record 949.5.

15 Genesis 24 describes the reign of "fire and brimstone" on Sodom and Gomorrah. One biblical scholar suggests that the association between sulfur and sexual sin may result from the Dead Sea's sulfuric stench. See J. Penrose Harland, "Sodom and Gomorrah: The Destruction of the Cities of the Plain," The Biblical Archaeologist 6 (1943): 41-54; and David Neev and K. O. Emery, The Destruction of Sodom, Gomorrah, and Jericho: Geological, Climatological, and Archaeological Background (New York: Oxford University Press, 1995). Similarly, Chaucer's Canon's Yeoman's Tale describes the hot, goatish stench of alchemical transformations that accrued to practitioners: "And everemoore, where that evere they goon, / Men may hem knowe by smel of brymstoon" (VIII, 884-85). Citations of Chaucer are from Larry D. Benson, gen. ed., The Riverside Chaucer, 3rd ed. (Boston: Houghton Mifflin, 1987).

16 Alan D. Justice, "Trade Symbolism in the York Cycle," Theatre Journal 31 (1979): 58.

17 Lancashire, Dramatic Texts, 293, record 1560.

248 Journal of Medieval and Early Modern Studies / 38.2 / 2008 
18 Justice, "Trade Symbolism in the York Cycle," 49.

19 Lancashire, Dramatic Texts, 110, record 529.

20 See, for example, Anne Higgins, "Work and Plays: Guild Casting in the Corpus Christi Drama," Medieval and Renaissance Drama 7 (1995): 76; and Jonathan Gil Harris, "Properties of Skill: Product Placement in Early English Artisanal Drama," in Staged Properties, ed. Harris and Korda, 35-66.

21 Higgins, "Work and Plays," 76.

22 Harris, "Properties of Skill," 42.

23 Edward Hall, The vnion of the two noble and illustre famelies of Lancastre [and] Yorke... (London, 1548), clxvii.

24 Pamela Nightingale, A Medieval Mercantile Community: The Grocers' Company and the Politics and Trade of London, 1000-1485 (New Haven, Conn.: Yale University Press, 1995), 81.

25 Thomas Dekker, The Magnificent Entertainment Giuen to King Iames, Queene Anne His Wife, and Henry Frederick the Prince, Vppon the Day of His Maiesties Tryumphant Passage (from the Tower) through His Honourable Cittie (and Chamber) of London... (London, 1604), sig. D2r.

26 Albert Feuillerat, ed., Documents Relating to the Office of the Revels in the Time of Queen Elizabeth (Louvain: A. Uystpruyst, 1908), 131, 40, 63-65, 67, 75-76, 98-99, 206, 208, 239, 308.

27 Ibid., 175, 199.

28 Mayoral processions emphasized London's port: these processions began on the Thames, went to Westminster for official ceremonies, returned to the Thames for water shows, headed to St. Paul's for land pageants, and finally ended with feasts at Guildhall. See Richmond Barbour, Before Orientalism: London's Theatre of the East, 1576-1626 (Cambridge: Cambridge University Press, 2003), 97.

29 The Grocers' Company sponsored the Triumphs of Honour and Industry; the Drapers' Company sponsored the Triumphs of Honour and Virtue. For a discussion of how these spectacles aided economic investment in the East India company and other types of global investments, see Barbour, Before Orientalism, 92; Yumna Siddiqi, "Dark Incontinents: The Discourse of Race and Gender in Three Renaissance Masques," Renaissance Drama 23 (1992): 139-63.

30 Thomas Middleton et al., The Works of Thomas Middleton, ed. A. H. Bullen, 8 vols. (London, 1885-86), 7:357-58.

31 A similar practice was employed in 1605 in Munday's mayoral pageant, the Triumphs of Re-United Britainia, which attempted to recreate Elizabeth's pageants. See David M. Bergeron and Harry B. Caldwell, Twentieth-Century Criticism of English Masques, Pageants, and Entertainments: 1558-1642 (San Antonio, Tex.: Trinity University Press 1972), 5-6.

32 Middleton et al., Works of Thomas Middleton, 236, 404-5.

33 See Jacqueline E. Jung, "Beyond the Barrier: The Unifying Role of the Choir Screen in Gothic Churches," The Art Bulletin 82 (2000): 624.

34 See E. G. Cuthbert and F. Atchley, A History of the Use of Incense in Divine Worship (London: Longmans, 1909); and Susan Ashbrook Harvey, Scenting Salvation: Ancient Christianity and the Olfactory Imagination (Berkeley: University of California Press, 2006). 
35 Such a connection between funeral rites and Christ's sacrifice "recalled both the purifying use of incense in funeral rites and the symbolic sacrifice of Christ." This association intensified at Easter: "censers figure prominently in the early iconography of the resurrection of Christ," particularly around representations of the three myrophores and their spices. See Elizabeth Parker McLachlan, "Liturgical Vessels and Implements," in Thomas J. Heffernan and E. Ann Matter, eds., The Liturgy of the Medieval Church (Kalamazoo, Mich.: Medieval Institute Publication, 2001), 409 and n. 120.

36 Heffernan and Matter, introduction to Liturgy of the Medieval Church, 7.

37 Stephen Mead, "Four-Fold Allegory in the Digby Mary Magdalene," Renascence 43 (1991): 279.

38 Though loose hair often signifies virginal innocence in medieval visual traditions, the Magdalene's loose hair is linked to her conversion and thus her previous sexual sins. See Katherine Jansen, The Making of the Magdalen: Preaching and Popular Devotion in the Later Middle Ages (Princeton, N.J.: Princeton University Press, 2000), 134.

39 Scholars debate whether the Digby Mary Magdalene reflects pre- or post-Reformation debates. The manuscript was transcribed by Myles Bloomfield in the first quarter of the sixteenth century, but its language suggests that it was probably first performed in the late fifteenth century. The lack of evidence surrounding the play's performance history suggests that the play could have been written and performed after the 1518 publishing of Jacques Lefèvre d'Étaples's attack on the Magdalene's composite biography and St. John Fisher's defense. See Clifford Davidson, "The Digby Mary Magdalene and the Magdalene Cult of the Middle Ages," Annuale Mediaevale 13 (1972): 71. Most scholars locate the writing of the play somewhere between 1480 and 1530. Theresa Colleti argues that the play is East Anglian, in Mary Magdalene and the Drama of Saints: Theater, Gender, and Religion in Late Medieval England (Philadelphia: University of Pennsylvania Press, 2004), 36.

40 Theresa Coletti, "Paupertas Est Donum Dei: Hagiography, Lay Religion, and the Economics of Salvation in the Digby Mary Magdalene," Speculum: A Journal of Medieval Studies 76 (2001): 313. In her more recent study of this play, Coletti argues that the Digby Mary Magdalene "exhibits thematic preoccupations and theatrical images that, viewed collectively, stunningly resonate with the spiritual ideology and activities of the late medieval hospital" (Mary Magdalene and the Drama of Saints, 39).

41 According to some legends, on this day the Magdalene received Communion in a church in Ephesus and died at the altar, after which "the church smelled of perfume for seven days, signaling her arrival in heaven." Ingrid Maisch, Mary Magdalene: The Imgage of a Woman through the Centuries (Collegeville, Minn.: Liturgical Press, 1998), 51. See Susan Haskins, Mary Magdalene: Myth and Metaphor (New York: Riverhead Books, 1993), 106-7; and Jansen, The Making of the Magdalen, 35-36.

42 Wickham, Early English Stages, 90.

43 Mead, "Four-Fold Allegory," 270.

44 See Coletti, Mary Magdalene and the Drama of Saints, 156-58.

45 Theresa Coletti, “'Curtesy Doth It Yow Lere': The Sociology of Transgression in the Digby Mary Magdalene," English Literary History 71 (2004): 1-28, at 2.

46 Donald C. Baker, John L. Murphy, and Louis B. Hall Jr., eds., The Late Medieval Religious Plays of Bodleian MSS Digby 133 and E Museuo 160 (Oxford: Oxford Uni- 
versity Press, 1982), 335-45; hereafter cited parenthetically by line numbers. Translations are my own.

47 Lady Lechery replies: "O ye prynse, how I am ful of ardent lowe [love], / Wyth sparkyllys [sparks] ful of amerowsnesse! / Wyth yow to rest fayn wold I aprowe [eagerly would I prove helpful], / To shew plesavns to your jentylnesse!” (353-56).

48 Galingale resembles a mild ginger root both in taste and smell and was very popular in medieval cookery. It is found both in southern Egypt and southeast Asia. Grains of paradise, an African spice, resembles a cross between pepper, ginger, and cardamom; clary is a type of sage found in England; marjoram is a sweet spice, native to northern Europe.

49 See Deanne Williams, The French Fetish from Chaucer to Shakespeare (New York: Cambridge Univeristy Press, 2004), 71. For an analysis of sodomy in the late medieval period, see Bruce Holsinger, "Sodomy and Resurrection: The Homoerotic Subject of the Divine Comedy," in Premodern Sexualities, ed. Louise Fradenburg and Carla Freccero (New York: Routledge, 1996), 243-74; Carolyn Dinshaw, Getting Medieval: Sexualities and Communities, Pre-and Postmodern (Durham, N.C.: Duke University Press, 1999). See also Mark Jordan, The Invention of Sodomy in Christian Theology (Chicago: University of Chicago Press, 1997).

50 In her most recent reading of this play, Theresa Coletti notes that these "queer moments of dramatic action have gone largely unremarked in scholarship." Coletti focuses on masculinity "as a preeminent dramatic locus of erotic energy and behavior," analyzing the pagan priest of Marseille's relationship with his clerk, the shipmaster, Nauta, and his boy, and finally the King of Marseille and the Nauta. See Mary Magdalene and the Drama of Saints, 159-61.

51 For a discussion of contrapasso, see Jansen, The Making of the Magdalen, 156.

52 Christ tells the Magdalene, "Wan that gardyn [of virtue] is watteryed wyth teyrs clere, / Than spryng vertuus, and smelle full sote" (1084-85).

53 Shakespeare's Cleopatra is based on both classical sources and contemporary travel narratives. See Pietro Martire d'Anghiera, The History of Tranayle in the West and East Indies, and Other Countreys Lying Eyther Way. . . , trans. Richard Eden and Richard Willes (London, 1577), 101, 39; Plutarch, The Lives of the Noble Grecians and Romanes Compared Together by That Graue Learned Philosopher and Historiographer, Plutarke..., trans. Thomas North (London, 1579).

54 All quotations from Antony and Cleopatra are from The Norton Shakespeare, Based on the Oxford Edition: Tragedies, ed. Stephen Greenblatt et al. (New York: Norton, 1997).

55 As he tries to leave Egypt, Antony foolishly locates Cleopatra’s power in her visual beauty: "Would I had never seen her" (1.2.138).

56 On the origins of the Magi tale and its popularity in late medieval Europe, see Marcia R. Rickard, "The Iconography of the Virgin Portal at Amiens," Gesta 22 (1983): 149.

57 Jonathan Gil Harris, “'Narcissus in Thy Face': Roman Desire and the Difference It Fakes in Antony and Cleopatra," Shakespeare Quarterly 45 (1994): 427 n. 38.

58 Leonard Tennenhouse, Power on Display: The Politics of Shakespeare's Genres (London: Methuen, 1986), 144, argues that "Cleopatra is Egpyt," embodying everything that is not Roman (or, for that matter, English).

59 See Barbour, Before Orientalism, 56 and 58; Janet Adelman, Suffocating Mothers: Fan- 
tasies of Maternal Origin in Shakespeare's Plays, "Hamlet" to "The Tempest" (New York: Routledge, 1992), 187; John Michael Archer, "Antiquity and Degeneration: The Representation of Egypt and Shakespeare's Antony and Cleopatra," Genre 27.1-2 (1994): 1-27, at 9; Walter Cohen, "Introduction: Antony and Cleopatra," in The Norton Shakespeare: Tragedies, ed. Greenblatt et al., 850; John Gillies, Shakespeare and the Geography of Difference (New York: Cambridge University Press, 1994), 120.

60 Barbara Hodgdon, "Antony and Cleopatra in the Theatre," in The Cambridge Companion to Shakespearean Tragedy, ed. Claire McEachern (Cambridge: Cambridge University Press, 2002), 241.

61 Jonathan Dollimore, "Shakespeare, Cultural Materialism, Feminism and Marxist Humanism," New Literary History 21 (1990): 487.

62 All citations from Twelfth Night are from The Norton Shakespeare, Based on the Oxford Edition: Comedies, ed. Stephen Greenblatt et al. (New York: Norton, 2000). To paraphrase both Orsino and Sir Toby Belch, Olivia is both plague and cure. Her devotion to her brother's memory has removed her from matrimonial spheres: "for [her brother's] dear love, / They say, she hath abjured the sight / And company of men" (1.2.35-37).

63 Jean Howard argues that Twelfth Night's structures of gender and desire reward Viola and punish Olivia. See "Crossdressing, the Theatre, and Gender Struggle in Early Modern England," Shakespeare Quarterly 39 (1988): 430-32.

64 Callaghan, Shakespeare without Women, 36.

65 Ibid., 36.

66 For an extended analysis of the significance of this scene, see Orgel, Impersonations, 50. 